\title{
Patho-epidemiological study on Genotype-XIII Newcastle disease virus infection in commercial vaccinated layer farms
}

\author{
J. H. Khorajiya ${ }^{1}$, Sunanda Pandey ${ }^{1}$, Priya D. Ghodasara ${ }^{1}$, B. P. Joshi $^{1}$, K. S. Prajapati ${ }^{1}$, D. J. Ghodasara ${ }^{1}$ \\ and R. A. Mathakiya ${ }^{2}$
}

1. Department of Veterinary Pathology, College of Veterinary Science and Animal Husbandry, Anand Agricultural University, Anand, Gujarat - 388 001, India; 2. Department of Veterinary Microbiology, College of Veterinary Science and Animal Husbandry, Anand Agricultural University, Anand, Gujarat - 388 001, India.

Corresponding author: Sunanda Pandey, e-mail: drsunandapandey@gmail.com,

JHK: jainudeen_1990@rediffmail.com,PDG: pdghodasara.vet@gmail.com, BPJ: b4bpjoshi@gmail.com,

KSP: kanti_prajapati@yahoo.com, DJG: dinghodasara@gmail.com, RAM: dr_ramathakiya@yahoo.co.in

Received: 30-11-2014, Revised: 12-01-2015, Accepted: 16-01-2015, Published online: 21-03-2015

doi: 10.14202/vetworld.2015.372-381, How to cite this article: Khorrajiya JH, Pandey S, Ghodasara PD, Joshi BP, Prajapati KS, Hodasara DJ, Mathakiya RA (2015) Patho-epidemiological study on genotype-XIII Newcastle disease virus infection in commercial vaccinated layer farms. Veterinary World 8(3):372-381.

\begin{abstract}
Aim: The present research work was carried out to study the patho-epidemiological aspects of Genotype-XIII Newcastle disease virus (NDV) infection in commercial layer in and around Anand, Gujarat. As the outbreaks have reported in vaccinated flocks, it was felt necessary to study the disease with respect to its changing pathogenicity and relevant aspects.

Materials and Methods: The study comprised of patho-epidemiology of Newcastle disease (ND) by information collected from different layer farms suffering from the disease in relation to incidence pattern and mortality, duration of mortality, susceptible age, and loss due to production performance. Clinical signs were recorded based on observations. During postmortem, gross lesions were also recorded. For histopathological examination visceral organs according to lesions were collected in $10 \%$ formalin and processed slide stained by hematoxylin and eosin for microscopic examination. Cultivation of virus was done in embryonated specific pathogen-free (SPF) eggs of 9-11 days and isolation of virus was done for haemagglutination (HA) and haemagglutination inhibition (HI) test and to identify pathotype of virus by intracerebral pathogenicity index (ICPI) test to determine the virulence of virus. The Genotype-XIII NDV was confirmed by F gene sequence and whole genome sequence.
\end{abstract}

Results: During the study mortality due to ND was recorded in 13 layer flocks in spite of routine vaccination, which usually contain Genotype-II strain of virus. The mortality was observed as high as above 50\% with an average of $21.21 \%$. The susceptible age for disease was found to be 6-14 weeks. The duration of mortality observed was 23 days. The disease resulted in a significant reduction in body weight, feed intake and drop in egg production. Majority of the outbreaks appeared during extremely hot months of April to June. Greenish diarrhoea was frequently seen in birds that survived early in infection. Mortality continued for 2-3 weeks and reduced with appearance of torticollis. Gross lesions were characterized by multifocal to diffuse hemorrhages around proventricular glands, necrotic (diphtheritic) haemorrhagic ulcers throughout the intestine, disseminated multiple foci of necrosis and pin-point hemorrhages in the spleen parenchyma. The microscopic lesions include focal to diffuse hemorrhages, diffuse infiltration of mononuclear cells, necrosis, and degeneration in visceral organs. All the 13 farm samples ( $\mathrm{n}=13)$ resulted in death of all the embryos following incubation up to $72 \mathrm{~h}$ post-inoculation. All the 13 allantois fluids from field samples along with F and R2B vaccine sample were found positive for HA activity, which was further confirmed by HI using known NDV serum. The values of ICPI were 2.0 which were indicative of velogenic nature of the field NDV strain.

Conclusion: The study indicated that presently available live and attenuated vaccines which include Genotype-II NDV have failed in protecting the flocks against Genotype-XIII and resulted in outbreaks with mortality above 50\%. ICPI score of 2.0 confirmed that the present outbreaks were due to Genotype-XIII NDV, which is velogenic in nature.

Keywords: genotype, histopathology, intra-cerebral pathogenicity index, Newcastle disease.

\section{Introduction}

Indian poultry industry is one of the fastest growing segments of the agricultural sector in India. Presently India has emerged as the World's second largest poultry market with an annual growth of more than 14\%, producing 66 billion eggs in 2012 [1]. However, a marked increase in poultry population along with the drastic changes in the husbandry

Copyright: The authors. This article is an open access article licensed under the terms of the Creative Commons Attributin License (http:// creative commons.org/licenses/by/2.0) which permits unrestricted use, distribution and reproduction in any medium, provided the work is properly cited. practices resulted in an increase in the prevalence and altered patterns of the poultry diseases. The presence of diseases in the poultry flock has reflected in inferior performance and has consistently been a major limiting factor to profitable production. Newcastle disease (ND) is an Office International des epizootics (OIE) listed infection and considered as one of the most important diseases of chicken [2]. It causes huge economic losses to farmers in the form of mortality and heavy production loss. Depending upon the pathotype and susceptibility of birds the mortality varies from $0 \%$ to $100 \%$ [3]. Since its first report in India between 1928 and 1930 at Ranikhet [4] 
and Madras-Chennai [5] it still remains endemic in India and outbreaks are reported regularly in spite of vaccination. The OIE defines ND as an infection caused by a highly virulent Avian Paramyxo virus-1 (APMV-1), an isolate that has either an intra-cerebral pathogenicity index (ICPI) of at least 0.7 in day-old chicks, or an amino acid sequence with multiple basic amino acids (at least three arginine (R) or lysine (K) residues at the $\mathrm{C}$-terminus of the $\mathrm{F} 2$ protein starting at position 113 , along with a phenylalanine at position 117 at $\mathrm{N}$-terminus of the F1 protein. APMV-1 is a member of the genus Avulavirus in the family Paramyxoviridae of the order Mononegavirales [6]. The Paramyxoviruses isolated from avian species have been classified into eleven subtypes designated APMV-1 to APMV-11 by serological testing and phylogenetic analysis [7]. Based on phylogenetic analysis with the partial hypervariable nucleotide sequences of the F gene, NDV strains have been classified into 18 genotypes (Class II, Genotypes I-XVIII). Recent reports from West and Central Africa described the presence of novel VNDV strains belonging to new genetic lineages closely related to Genotype VII namely XIV, XVII and XVIII [8].

ND is endemic in many parts of the world including countries in Asia, the Middle East, Africa, and Central and South America. In terms of economic impact, no other poultry virus comes even close to NDV. It may represent a bigger drain on the livestock economy than any other animal virus. In spite of a stringent vaccination policy against ND, outbreaks still occur in many countries.

During recent years outbreaks of ND in commercial layer farms were observed around Anand, Gujarat. Failure of vaccination programme also suspected emergence of the new genotype of NDV. As the outbreaks have reported in vaccinated flocks, it was felt necessary to study the disease with respect to its changing pathogenicity and related relevant aspects.

\section{Materials and Methods}

\section{Ethical approval}

The present study was approved by Institutional Animal Ethics Committee. The authors have taken permission from each poultry farm owner to publish data.

\section{Epidemiological study}

The information regarding epidemiological study was obtained by making personal visits to the commercial layer farms situated around Anand, Gujarat where mortality was reported due to ND with regular vaccination programme. The information like name and location of farm, strength of flock, age of the flock when ND was first detected, mortality pattern, duration of mortality (Period for which mortality continues in the farm during outbreak), effect on body weight, production drop, effect on feed consumption, history of vaccination, type of vaccination were recorded. Total 13 layer farms were visited where mortality due to Newcastle disease virus (NDV) was reported.

\section{Gross pathology}

During the outbreak of disease in the layer farms, the ailing birds were examined for clinical signs if any and detailed post-mortem was carried out from the carcass in the Department of Pathology and gross pathological lesions were recorded. The gross pathological lesions were recorded and characterized depending upon the severity of the disease as well as concominent other lesions suggestive of secondary bacterial infections like Escherichia coli or Mycoplasma.

\section{Histopathological study}

For histopathological examination, tissues from visceral organs like lung, trachea, liver, spleen, kidney, proventriculus, intestine, caecal tonsils, bursa of Fabricious and brain were collected in $10 \%$ neutral buffered formalin and processed by paraffin embedding technique. Sections were cut at 5-6 $\mu$ thickness with automatic section cutting machine (Leica, Germany) and stained with haematoxylin and eosin ( $\mathrm{H}$ and $\mathrm{E}$ ) [9]. The $\mathrm{H}$ and $\mathrm{E}$ stained sections were observed under the light microscope, and lesions were recorded.

\section{Collection of samples for virological study (NDV propagation in egg embryo)}

At the time of post-mortem examination, the carcasses showing gross lesions suggestive of ND were selected for collection of samples for detection of NDV i.e. Propagation and cultivation of NDV in specific pathogen-free egg embryo. After taking necessary aseptic precautions, the pooled tissue samples of trachea, lung, spleen, proventriculus, caecal tonsils and intestine representative of each layer farms were collected separately in sterile petridish for further processing. A total of 13 samples from 13 farms were collected, and the tissues from each farm were pooled and processed as a single sample.

\section{NDV}

Reference virus strains ( $\mathrm{F}$ and R2B) of NDV obtained from the Vaccine Institute, Gandhinagar were used for control study.

\section{Cultivation of NDV in egg embryo}

Inoculation in embryo through allantoic route and collection of allantoic fluid carried out as per the method described in OIE Terrestrial Manual 2012 [10].

\section{HA and HI tests}

To isolate virus both the test was carried out as per the method described in OIE Terrestrial Manual 2012.

\section{Pathogenicity index}

ICPI is an accepted in vivo test for the assessment of virulence of NDV in 1-day-old chicks because of its established accuracy and sensitivity (OIE Terrestrial Manual 2012). During the study, representative 
samples of different layer farms were inoculated in day old chicks and were pathotyped performing ICPI to evaluate the virulence of the field isolates as stated by Alexander and Senne [11].

The present field isolates obtained during field outbreaks of ND from layer and broiler farms were submitted to Department of Microbiology for F gene sequence and to Department of Animal Biotechnology for whole genome sequencing. The Genome length found was 15192nt. The phylogenetic analysis and evolutionary distances placed these isolates in Genotype XIII (XIIIb) with the available latest sequences in the gene bank.

\section{Results}

The results obtained from this study have been summarized under the following headings and are described with the help of different tables.

\section{Epidemiological studies}

ND was reported in thirteen layer farms around Anand, Gujarat, India in spite of routine vaccination programme during the period March 2013 to April 2014. Anand is located at $22.57^{\circ} \mathrm{N} 72.93^{\circ} \mathrm{E}$. The day temperature in winter is around $83^{\circ} \mathrm{F}$ and at night is $53^{\circ} \mathrm{F}$. Summers are extremely hot, with the day temperature being $115^{\circ} \mathrm{F}$, and the night temperature being $90^{\circ} \mathrm{F}$. In Gujarat, monsoon is generally hot and utterly humid. The temperature at day is $100^{\circ} \mathrm{F}$ but at night it falls down to $80^{\circ} \mathrm{F}$.

\section{Strength and age of the flock when ND first detected}

The strength of the affected flocks in different farms ranged between 4320 and 33764 birds (Table-1). The outbreaks of ND in all the flocks studied were in the age group ranging between 5 and 36 weeks. The disease was noticed as early as 33 days to as later on 252 days of age. All the affected flocks were housed in cage system of management.

\section{Mortality}

Mortality due to ND in all the thirteen flocks was ranged between 6.53 and $53.88 \%$. The overall mortality was $21.21 \%$. Among different layer birds mortality in layer chicks ranged from $13.26 \%$ to $53.88 \%$, in growers 9.14-19.21\%, and in layers 6.53-9.65\% (Table-1). Younger flocks had higher mortality due to low vaccinal immunity resulting from less number of vaccinations. The death was reported daily without any control in spite of vaccination and medication. The duration of mortality recorded in all the layer farms was as short duration as 13 days at Yogi poultry Farm, Sarsa and as long duration as 46 days at Bhoomi poultry Farm, Sarsa. The overall duration of mortality was 23 days (Table-1).

\section{Vaccination history}

As per available records on each of the affected farms it was noticed that the affected layer flocks were vaccinated with Lasota $(\mathrm{D} / \mathrm{W})$ and lentogenic ND Killed $0.25 \mathrm{ml}(\mathrm{S} / \mathrm{C})$ at neck region in 1st week (Flock no. 1, 2, 3) further Lasota boostering was done at $5^{\text {th }}$ week (Flock no. 4, 5, 6, 7 and 8), $\mathrm{R}_{2} \mathrm{~B} 0.5 \mathrm{ml}(\mathrm{I} / \mathrm{M})$ at 10th week (Flock No. 9, 10 and 11), Lasota (D/W) and Lentogenic ND killed $0.5 \mathrm{ml}(\mathrm{S} / \mathrm{C})$ during prelay stage at $20^{\text {th }}$ week and Lasota $(\mathrm{D} / \mathrm{W})$ at $35^{\text {th }}$ weeks of age (Flock No. 12 and 13). The vaccination schedule was followed as per standard guidelines using cold chain.

\section{Effect on feed consumption}

The entire affected layer flocks revealed reduction in feed intake ranging from $3.46 \%$ to $46.91 \%$. In the majority of the farms (10/13) feed intake was reduced above $17 \%$, whereas in three farms it was reduced below $10 \%$ in comparison to the standard feed intake (Table-2).

\section{Effect on body weight}

The entire affected layer flocks revealed depression in body weight ranging from $13.85 \%$ to $42.37 \%$. Majority of farms (11/13) revealed depression in body weight above $19 \%$ during the course of the disease as compared to standard body weight as per the guidelines given by hatchery (Table-2).

\section{Seasonal distribution}

During the study period, it was observed that majority of the outbreaks (11/13) were reported in the summer months of April to June while only two farms showed the presence of disease in the month of January and February. The seasonal distribution pattern indicated that birds were more prone for the disease in summer months than winter months (Table-2).

\section{Effect on production}

Out of total thirteen flocks affected with the disease, only two farms were in laying phase. As per the available data of production performance, both these flocks revealed drop in egg production during the course of the disease. The drop in egg production was from $89.28 \%$ to $56.44 \%$ in Keval Poultry farm Sarsa, and from $89.4 \%$ to $68.0 \%$ in Honest Poultry Farm, Flock No-A, Sarsa. Production reached up to $84 \%$ after 6 weeks at Keval Poultry farm Sarsa, and up to $86 \%$ after 4 weeks at Honest Poultry Farm, Flock No-A, Sarsa. But none of the farms reached up to original production more than $86 \%$ during laying phase. Both these laying flocks showed 20-30\% drop in hen day egg production. There was a slow recovery after a month but failed to reach original production level. The appearance of lethargy eggs and eggshell breakage which are usually seen with classical ND outbreaks were not severe in the present outbreaks.

\section{Clinical signs}

At the beginning, the disease appeared suddenly with high mortality without any clinical signs in the entire affected layer. Subsequently clinical signs appeared gradually. They include reduced feed intake, listlessness, increased respiration, Greenish diarrhoea with soiled feathers of vent, dehydration, 
Table-1: Information regarding flock strength, age of the flock when ND first detected, total mortality, duration of mortality and vaccination history in commercial layer farms affected with ND.

\begin{tabular}{|c|c|c|c|c|c|c|c|c|}
\hline \multirow{2}{*}{$\begin{array}{l}\text { Name and } \\
\text { location of } \\
\text { farm }\end{array}$} & \multirow{2}{*}{$\begin{array}{c}\text { Flock } \\
\text { strength }\end{array}$} & \multirow{2}{*}{$\begin{array}{l}\text { Age of the } \\
\text { flock when } \\
\text { ND first } \\
\text { detected } \\
\text { (days) }\end{array}$} & \multirow{2}{*}{$\begin{array}{l}\text { Total no } \\
\text { of bird } \\
\text { died }\end{array}$} & \multirow{2}{*}{$\begin{array}{c}\text { Mortality } \\
\%\end{array}$} & \multirow{2}{*}{$\begin{array}{l}\text { No of days for } \\
\text { which mortality } \\
\text { continues } \\
\text { during outbreak } \\
\text { (days) }\end{array}$} & \multicolumn{3}{|c|}{ Vaccination history } \\
\hline & & & & & & $\begin{array}{l}\text { Type of } \\
\text { vaccine }\end{array}$ & $\begin{array}{l}\text { Schedule of } \\
\text { vaccination } \\
\text { (weeks) }\end{array}$ & $\begin{array}{l}\text { Dose and } \\
\text { route }\end{array}$ \\
\hline $\begin{array}{l}\text { Arpan Poultry } \\
\text { Farm, Navli }\end{array}$ & 8150 & 33 & 2518 & 25 & 24 & $\begin{array}{l}\text { Lasota } \\
\text { ND Killed }\end{array}$ & $\begin{array}{l}1 \\
1\end{array}$ & $\begin{array}{l}\text { Drinking water } \\
0.3 \mathrm{ml} \mathrm{S} / \mathrm{C}\end{array}$ \\
\hline $\begin{array}{l}\text { Bhoomi Poultry } \\
\text { Farm, Sarsa }\end{array}$ & 33764 & 34 & 18194 & 53.88 & 46 & $\begin{array}{l}\text { Lasota } \\
\text { ND killed }\end{array}$ & $\begin{array}{l}1 \\
1\end{array}$ & $\begin{array}{l}\text { Drinking water } \\
0.3 \mathrm{ml} \mathrm{S} / \mathrm{C}\end{array}$ \\
\hline $\begin{array}{l}\text { Narayan Poultry } \\
\text { Farm, Navli }\end{array}$ & 6361 & 34 & 844 & 13.26 & 26 & $\begin{array}{l}\text { Lasota } \\
\text { ND Killed }\end{array}$ & $\begin{array}{l}1 \\
1\end{array}$ & $\begin{array}{l}\text { Drinking water } \\
0.25 \mathrm{ml} \mathrm{S} / \mathrm{C}\end{array}$ \\
\hline $\begin{array}{l}\text { Samarpan } \\
\text { Poultry Farm, } \\
\text { Navli }\end{array}$ & 15319 & 36 & 3912 & 25.53 & 20 & $\begin{array}{l}\text { Lasota } \\
\text { ND killed } \\
\text { Lasota }\end{array}$ & $\begin{array}{l}1 \\
1 \\
5\end{array}$ & $\begin{array}{l}\text { Drinking water } \\
0.25 \mathrm{ml} \mathrm{S/C} \\
\text { Drinking water }\end{array}$ \\
\hline $\begin{array}{l}\text { Radhekrishna } \\
\text { Poultry Farm, } \\
\text { Verakhadi }\end{array}$ & 15240 & 43 & 5880 & 38.58 & 23 & $\begin{array}{l}\text { Lasota } \\
\text { ND killed } \\
\text { Lasota }\end{array}$ & $\begin{array}{l}1 \\
1 \\
5\end{array}$ & $\begin{array}{l}\text { Drinking water } \\
0.25 \mathrm{ml} \mathrm{S} / \mathrm{C} \\
\text { Eye Drop }\end{array}$ \\
\hline $\begin{array}{l}\text { J.K Poultry Farm, } \\
\text { Sarsa }\end{array}$ & 11229 & 60 & 2927 & 26.06 & 27 & $\begin{array}{l}\text { Lasota } \\
\text { ND killed } \\
\text { Lasota }\end{array}$ & $\begin{array}{l}1 \\
1 \\
5\end{array}$ & $\begin{array}{l}\text { Drinking water } \\
0.25 \mathrm{ml} \mathrm{S} / \mathrm{C} \\
\text { Drinking water }\end{array}$ \\
\hline $\begin{array}{l}\text { Shradha Poultry } \\
\text { Farm Flock -B, } \\
\text { Sarsa }\end{array}$ & 5283 & 60 & 1015 & 19.21 & 22 & $\begin{array}{l}\text { Lasota } \\
\text { ND killed } \\
\text { Lasota }\end{array}$ & $\begin{array}{l}1 \\
1 \\
5\end{array}$ & $\begin{array}{l}\text { Drinking water } \\
0.25 \mathrm{ml} \mathrm{S} / \mathrm{C} \\
\text { Drinking water }\end{array}$ \\
\hline $\begin{array}{l}\text { Yogi Poultry } \\
\text { Farm, Sarsa }\end{array}$ & 4320 & 68 & 395 & 9.14 & 13 & $\begin{array}{l}\text { Lasota } \\
\text { ND Killed } \\
\text { Lasota }\end{array}$ & $\begin{array}{l}1 \\
1 \\
5\end{array}$ & $\begin{array}{l}\text { Drinking water } \\
0.25 \mathrm{ml} \mathrm{S} / \mathrm{C} \\
\text { Drinking water }\end{array}$ \\
\hline $\begin{array}{l}\text { Honest Poultry } \\
\text { Farm Flock } \\
\text { No- B, Sarsa }\end{array}$ & 11597 & 74 & 1640 & 14.14 & 25 & $\begin{array}{l}\text { Lasota } \\
\text { ND killed } \\
\text { Lasota } \\
\text { R2B }\end{array}$ & $\begin{array}{c}1 \\
1 \\
5 \\
10\end{array}$ & $\begin{array}{l}\text { Drinking water } \\
0.25 \mathrm{ml} \mathrm{S} / \mathrm{C} \\
\text { Drinking water } \\
0.5 \mathrm{~m} . \mathrm{I} / \mathrm{M}\end{array}$ \\
\hline $\begin{array}{l}\text { Shradha Poultry } \\
\text { Farm Flock No-A, } \\
\text { Sarsa }\end{array}$ & 5335 & 88 & 2927 & 16.1 & 25 & $\begin{array}{l}\text { Lasota } \\
\text { ND killed } \\
\text { Lasota } \\
\text { R2B }\end{array}$ & $\begin{array}{c}1 \\
1 \\
5 \\
10\end{array}$ & $\begin{array}{l}\text { Drinking water } \\
0.25 \mathrm{ml} \mathrm{S} / \mathrm{C} \\
\text { Drinking water } \\
0.5 \mathrm{~m} . \mathrm{I} / \mathrm{M}\end{array}$ \\
\hline $\begin{array}{l}\text { Adarsh Poultry } \\
\text { Farm, Kasor }\end{array}$ & 13911 & 97 & 2594 & 18.64 & 15 & $\begin{array}{l}\text { Lasota } \\
\text { ND killed } \\
\text { Lasota } \\
\text { R2B }\end{array}$ & $\begin{array}{c}1 \\
1 \\
5 \\
10\end{array}$ & $\begin{array}{l}\text { Drinking water } \\
0.25 \mathrm{ml} \mathrm{S} / \mathrm{C} \\
\text { Drinking water } \\
0.5 \mathrm{~m} . \mathrm{I} / \mathrm{M}\end{array}$ \\
\hline $\begin{array}{l}\text { Honest Poultry } \\
\text { Farm Flock No-A, } \\
\text { Sarsa }\end{array}$ & 10512 & 244 & 686 & 6.53 & 17 & $\begin{array}{l}\text { Lasota } \\
\text { ND killed } \\
\text { Lasota } \\
\text { R2B } \\
\text { Lasota } \\
\text { ND killed } \\
\text { Lasota }\end{array}$ & $\begin{array}{c}1 \\
1 \\
5 \\
10 \\
20 \\
20 \\
35\end{array}$ & $\begin{array}{l}\text { Drinking water } \\
0.25 \mathrm{ml} \mathrm{S} / \mathrm{C} \\
\text { Drinking water } \\
0.5 \mathrm{~m} . \mathrm{I} / \mathrm{M} \\
\text { Drinking water } \\
0.5 \mathrm{ml} \mathrm{S} / \mathrm{C} \\
\text { Drinking water }\end{array}$ \\
\hline $\begin{array}{l}\text { Keval Poultry } \\
\text { Farm, Sarsa }\end{array}$ & 12087 & 252 & 1166 & 9.65 & 21 & $\begin{array}{l}\text { Lasota } \\
\text { ND killed } \\
\text { Lasota } \\
\text { R2B } \\
\text { Lasota } \\
\text { ND killed } \\
\text { Lasota }\end{array}$ & $\begin{array}{c}1 \\
1 \\
5 \\
10 \\
20 \\
20 \\
35\end{array}$ & $\begin{array}{l}\text { Drinking water } \\
0.25 \mathrm{ml} \mathrm{S} / \mathrm{C} \\
\text { Drinking water } \\
0.5 \mathrm{~m} . \mathrm{I} / \mathrm{M} \\
\text { Drinking water } \\
0.5 \mathrm{ml} \mathrm{S} / \mathrm{C} \\
\text { Drinking water }\end{array}$ \\
\hline
\end{tabular}

$\mathrm{ND}=$ Newcastle disease

loss in body weight, conjunctivitis, prostration and increasing mortality. Some of the flocks also showed oedema around eyes and head. Greenish diarrhoea (Figure-1) was frequently seen in birds that survived early in infection. Mortality continued for 2-3 weeks and reduced with appearance of torticollis. Birds with torticollis (Figure-2) showed lingering mortality. Among the laying flocks there was $20-30 \%$ drop in hen day egg production which showed slow recovery after 5-6 weeks but failed to reach original production level.

\section{Pathological studies}

Gross pathology

Gross pathological lesions observed in all the layer flocks were typically of velogenic viscerotropic ND. The lesions were characterized by emaciation and dehydration of carcass with deep congestion of breast musculature, multifocal to diffuse haemorrhages around proventricular gland, necrotic (diphtheritic) haemorrhagic ulcers throughout the intestine and caecal tonsils (Figure-3). In addition to the disseminated multiple foci of necrosis, pin-point haemorrhages 
Table-2: Information regarding Name of the farm, effect on body weight, effect on feed consumption and seasonal distribution in commercial layer farms affected with ND.

\begin{tabular}{|c|c|c|c|c|c|c|c|}
\hline $\begin{array}{l}\text { Name and location } \\
\text { of farm }\end{array}$ & $\begin{array}{c}\text { Average feed } \\
\text { consumption } \\
\text { during } \\
\text { course of } \\
\text { disease }(g)\end{array}$ & $\begin{array}{c}\text { Standard } \\
\text { normal } \\
\text { feed intake } \\
\text { BV=300 (g) }\end{array}$ & $\begin{array}{c}\text { Percent } \\
\text { Reduction in } \\
\text { feed intake } \\
\text { during course } \\
\text { of disease }\end{array}$ & $\begin{array}{c}\text { Average } \\
\text { body weight } \\
\text { during } \\
\text { course of } \\
\text { disease }(\mathrm{g})\end{array}$ & $\begin{array}{c}\text { Standard } \\
\text { normal } \\
\text { body weight } \\
\text { in gram } \\
\text { BV=300 }\end{array}$ & $\begin{array}{l}\text { Percent } \\
\text { reduction in } \\
\text { body weight } \\
\text { during course } \\
\text { of disease }\end{array}$ & $\begin{array}{l}\text { Month of } \\
\text { outbreak }\end{array}$ \\
\hline $\begin{array}{l}\text { Arpan Poultry Farm, } \\
\text { Navli }\end{array}$ & 38.99 & 42.56 & 8.38 & 398 & 462 & 13.85 & February \\
\hline $\begin{array}{l}\text { Bhoomi Poultry Farm, } \\
\text { Sarsa }\end{array}$ & 29.54 & 46.93 & 37.05 & 498 & 626 & 20.44 & June \\
\hline $\begin{array}{l}\text { Narayan Poultry } \\
\text { Farm, Navli }\end{array}$ & 29.59 & 43.88 & 32.56 & 365 & 506 & 27.86 & May \\
\hline $\begin{array}{l}\text { Samarpan Poultry } \\
\text { Farm, Navli }\end{array}$ & 39.36 & 43.57 & 10 & 335 & 480 & 30.20 & January \\
\hline $\begin{array}{l}\text { Radhekrishna Poultry } \\
\text { Farm, Veraikhadi }\end{array}$ & 32.64 & 47.26 & 30.93 & 346 & 590 & 42.37 & May \\
\hline $\begin{array}{l}\text { J.K Poultry Farm, } \\
\text { Sarsa }\end{array}$ & 49.87 & 51.66 & 3.46 & 636 & 813 & 21.77 & May \\
\hline $\begin{array}{l}\text { Shradha Poultry Farm } \\
\text { Flock -B, Sarsa }\end{array}$ & 40.22 & 50.86 & 20.92 & 632 & 786 & 19.59 & June \\
\hline $\begin{array}{l}\text { Yogi Poultry Farm, } \\
\text { Sarsa }\end{array}$ & 35.24 & 51.46 & 31.51 & 640 & 822 & 22.14 & May \\
\hline $\begin{array}{l}\text { Honest Poultry Farm } \\
\text { Flock No-B, Sarsa }\end{array}$ & 29.39 & 55.36 & 46.91 & 761 & 954 & 20.48 & May \\
\hline $\begin{array}{l}\text { Shradha Poultry Farm } \\
\text { Flock No-A, Sarsa }\end{array}$ & 49.24 & 59.44 & 17.16 & 876 & 1012 & 13.43 & April \\
\hline $\begin{array}{l}\text { Adarsh Poultry Farm, } \\
\text { Kasor }\end{array}$ & 49.94 & 60.82 & 17.88 & 900 & 1107 & 18.69 & June \\
\hline $\begin{array}{l}\text { Honest Poultry Farm } \\
\text { Flock No- A, Sarsa }\end{array}$ & 68.92 & 96.02 & 28.23 & 1220 & 1220 & 0.0 & April \\
\hline $\begin{array}{l}\text { Keval Poultry Farm, } \\
\text { Sarsa }\end{array}$ & 78.71 & 95.71 & 17.76 & 1220 & 1220 & 0.0 & April \\
\hline
\end{tabular}

$\mathrm{ND}=$ Newcastle disease

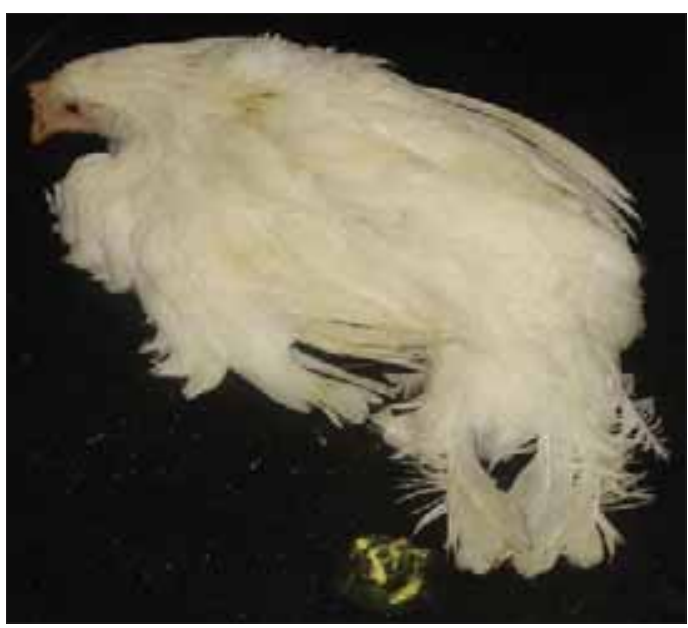

Figure-1: Layer bird affected with Newcastle disease showing greenish diarrhoea and depression.

were observed in the spleen parenchyma. Severe congestion of trachea and lungs was a prominent feature in the majority of layer chicks. In addition, the laying flocks showed degenerated, misshapen and haemorrhagic ova with lesion of egg peritonitis.

\section{Histopathology}

Proventriculus

The lesions obtained were focal to diffuse haemorrhages within mucosal ridges as well as in the glandular regions of proventriculus and were suggestive of

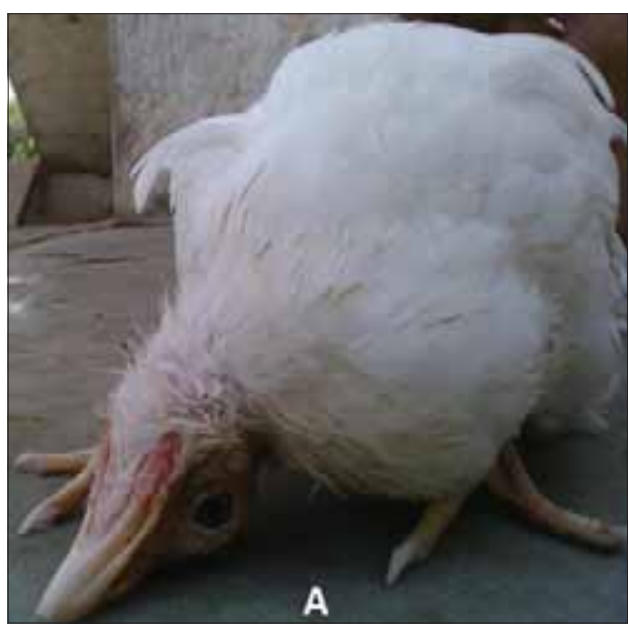

Figure-2: Layer bird affected with Newcastle disease showing characteristic symptoms of torticollis (twisted neck and paralysis).

haemorrhagic proventriculitis (Figure-4). Along with haemorrhages, there was diffuse infiltration of lymphocyte in the mucosa with shortening and sloughing of proventricular papillae.

\section{Intestine}

Grossly visible diphtheritic and haemorrhagic ulcers revealed lesions like degeneration, necrosis and sloughing of epithelial cells covering from tip of villi to muscular is mucosa along with moderate to severe 


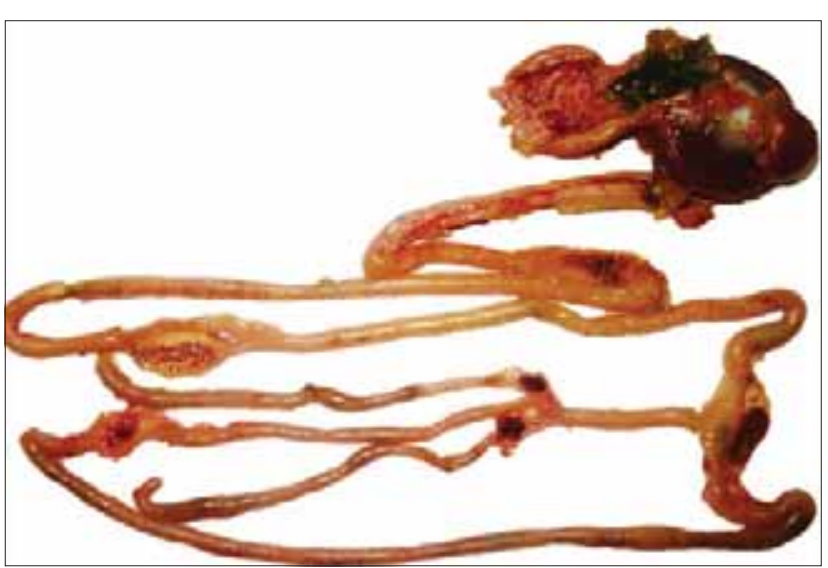

Figure-3: Proventriculus showing diffuse haemorrhages along with haemorrhagic and necrotic patches on intestine and caecal tonsils.

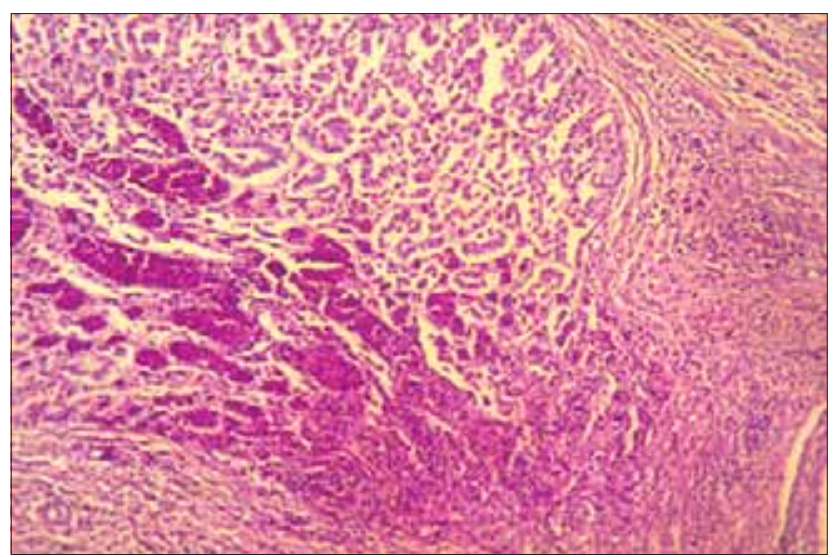

Figure-4: Section of proventriculus from a layer bird showing focal to diffuse haemorrhages in the mucosal and glandular region. $\mathrm{H}$ and $\mathrm{E}$ stain $\times 150$.

infiltration of mononuclear cells and focal to diffuse haemorrhages.

\section{Caecal tonsils}

The lesions in the tonsilar parenchyma revealed multifocal areas of necrosis and hemorrhages and moderate to diffuse infiltration of mononuclear cells, especially lymphocytes in mucosa and submucosa. Some of the sections also showed lymphoid depletion and presence of fibrin debris replacing the lymphoid cells.

\section{Spleen}

The lesions in the splenic parenchyma includes mild to moderate congestion, multifocal areas of lymphoid necrosis (Figure-5) and reticuloendothelial cell hyperplasia. The lesions were consistent and observed in the majority of flocks.

\section{Bursa of fabricius}

Bursa of fabricius was collected from layer flocks affected during early growing age. The bursal lesions revealed marked lymphoid necrosis and depletion in follicles with massive heterophilic infiltration in inter and intra-follicular space with cyst formation along with formation of intra-follicular glandular structures

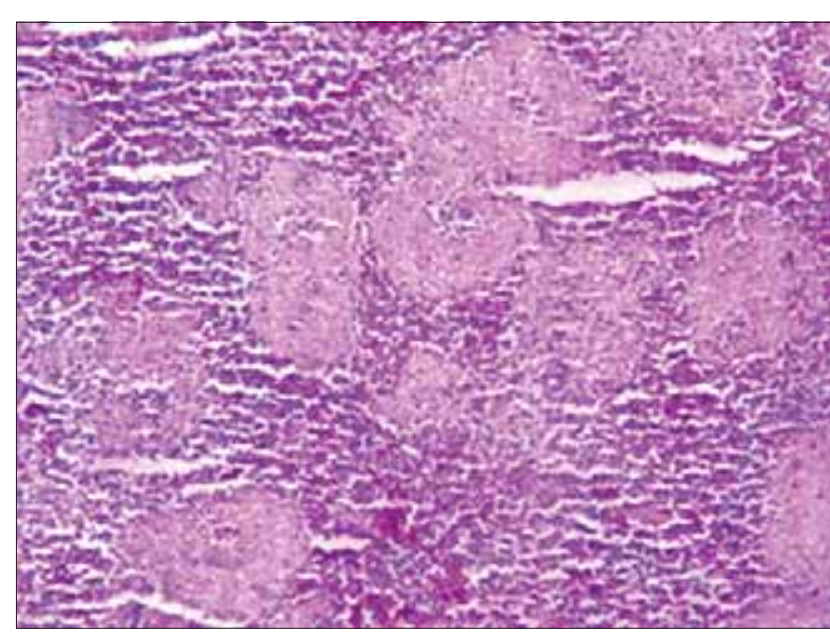

Figure-5: Section of spleen from a layer bird showing mild congestion and multi-focal areas of lymphoid necrosis. $\mathrm{H}$ and $\mathrm{E}$ stain $\times 150$.

with enormous proliferation of fibrous connective tissue in inter-follicular space.

\section{Trachea}

Tracheal lesions observed during the study were also consistent and seen in majority flocks in Birds. The lesions found in the trachea were variable and included loss of cilia, congestion, oedema and dense infiltration of lymphocytes and macrophages in the mucosa along with desquamation of tracheal mucosal lining epithelium.

\section{Lung}

The microscopic lesions observed in lung parenchyma were hyperemia and oedema of the parabronchi with infiltration of mononuclear cells. Focal to diffuse areas of haemorrhages were also observed in some of the areas. The lesion observed both in trachea and lungs were indicative of involvement of respiratory tract with much severity during the present outbreaks.

\section{Brain}

Lesions in the brain parenchyma though not consistent but were indicative of non-purulent encephalitis with neuronal degeneration. They included perivascular infiltration of lymphocytes, neuronal degeneration and foci of glial cells in the brain parenchyma (Figure-6). The lesions were observed only in few flocks of grower birds.

\section{Virus propagation in egg embryo}

All the 13 flock samples $(n=13)$ were inoculated in 9-11 days old embryonated SPF eggs, which resulted in death of all embryos following incubation up to $72 \mathrm{~h}$ post-inoculation, thereafter allantois fluid was harvested. The allantois fluid was then subjected to centrifugation at $10000 \mathrm{rpm}$ for $10 \mathrm{~min}$ for removal of cellular part. The embryos were taken out one by one in separate petri dishes and washed with nephron sparing surgery for observation of gross lesions produced by the virus. There were multiple haemorrhagic 


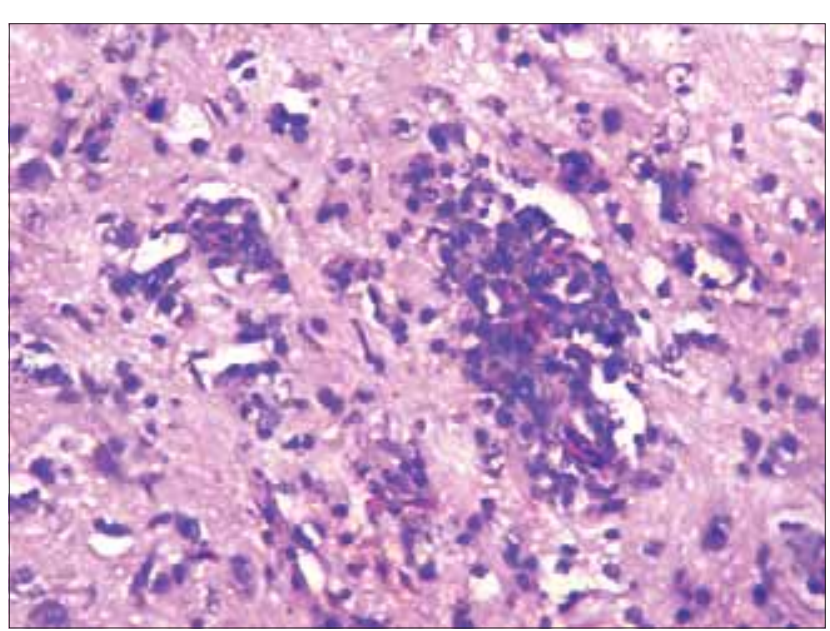

Figure-6: Section of brain from a layer bird showing neuronal degeneration and focal area of gliosis. $\mathrm{H}$ and $\mathrm{E}$ stain $\times 300$.

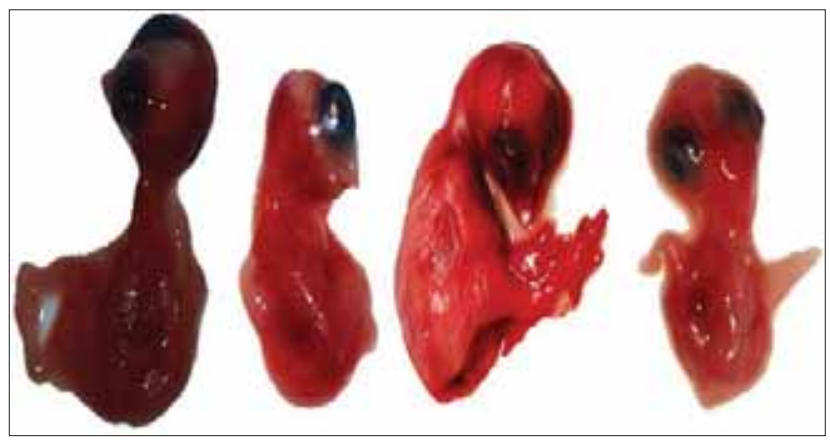

Figure-7: Egg embryos of SPF chicks infected with Newcastle disease virus showing haemorrhagic lesions on the body surface.

lesions produced throughout the surface of the body of the embryos particularly at the head region (Figure-7).

\section{HA and HI tests}

The test revealed the HA titers in all the 13 field samples and two vaccine sample in between the range of $2^{4}-2^{8}$. HA was confirmed by presence or absence of mat formation of the RBCs (Table-3). The titration was considered as positive at the highest dilution giving complete HA. The positive haemagglutinating allantoic fluids were tested by $\mathrm{HI}$ test with known NDV anti-serum and it showed the HI titers of $2^{3}-2^{9}$ (Table-4). The HI titer was considered as the highest dilution of serum causing complete inhibition of $4 \mathrm{HA}$ units of the antigen. The agglutination was assessed by tilting the plates, and streaming of RBCs was compared with control wells (positive-serum, virus and PBS controls) to record the results. Results of HA and $\mathrm{HI}$ confirmed the presence of NDV in allantoic fluids obtained from all the 13 of embryonated eggs inoculated with field samples.

Along with all the $13, \mathrm{NDV} F$ and $\mathrm{R}_{2} \mathrm{~B}$ (Reference strain) allantoic fluid samples were found positive for HA activity. Among these, two samples (15.38\%) had HA titer of $1: 16$ or below, ten samples $(76.92 \%)$ had titer between 1:16 and 1:64 and one samples (7.69\%) had titer of 1:128 and above. Higher titers indicated
Table-3: Results of HA test.

\begin{tabular}{lccc}
\hline Sample ID & No. of wells & HA titre & 4 HA unit \\
\hline NDV 1 & 6 & $2^{6}(1: 64)$ & $1: 16$ \\
NDV 2 & 6 & $2^{6}(1: 64)$ & $1: 16$ \\
NDV 3 & 6 & $2^{6}(1: 64)$ & $1: 16$ \\
NDV 4 & 6 & $2^{6}(1: 64)$ & $1: 16$ \\
NDV 5 & 4 & $2^{4}(1: 16)$ & $1: 4$ \\
NDV 6 & 4 & $2^{4}(1: 16)$ & $1: 4$ \\
NDV 7 & 6 & $2^{6}(1: 64)$ & $1: 16$ \\
NDV 8 & 5 & $2^{5}(1: 32)$ & $1: 8$ \\
NDV 9 & 6 & $2^{6}(1: 64)$ & $1: 16$ \\
NDV 10 & 6 & $2^{6}(1: 64)$ & $1: 16$ \\
NDV 11 & 6 & $2^{6}(1: 64)$ & $1: 16$ \\
NDV 12 & 6 & $2^{6}(1: 64)$ & $1: 16$ \\
NDV 13 & 8 & $2^{8}(1: 256)$ & $1: 64$ \\
NDV 14 (F vaccine) & 6 & $2^{6}(1: 64)$ & $1: 16$ \\
NDV 15 ( R2B) & 6 & $2^{6}(1: 64)$ & $1: 16$ \\
\hline
\end{tabular}

$\mathrm{NDV}=$ Newcastle disease virus, $\mathrm{HA}=$ Haemagglutination

Table-4: Results of HI test.

\begin{tabular}{lcc}
\hline Sample ID & No. of wells & HI titre \\
\hline NDV 1 & 4 & $2^{4}(1: 16)$ \\
NDV 2 & 3 & $2^{3}(1: 8)$ \\
NDV 3 & 5 & $2^{5}(1: 32)$ \\
NDV 4 & 9 & $2^{9}(1: 512)$ \\
NDV 5 & 6 & $2^{6}(1: 64)$ \\
NDV 6 & 2 & $2^{2}(1: 4)$ \\
NDV 7 & 2 & $2^{2}(1: 4)$ \\
NDV 8 & 5 & $2^{5}(1: 32)$ \\
NDV 9 & 3 & $2^{3}(1: 8)$ \\
NDV 10 & 4 & $2^{4}(1: 16)$ \\
NDV 11 & 3 & $2^{3}(1: 8)$ \\
NDV 12 & 9 & $2^{9}(1: 512)$ \\
NDV 13 & 3 & $2^{3}(1: 8)$ \\
NDV $14(F$ Vaccine) & 3 & $2^{3}(1: 8)$ \\
NDV 15(R2B) & 4 & $2^{4}(1: 16)$ \\
\hline NDV & 3 NCastedisease &
\end{tabular}

$\mathrm{NDV}=$ Newcastle disease virus, $\mathrm{HI}=$ Haemagglutination inhibition

more concentration of the virus in the respective samples.

HA positive 13 samples and the reference $\mathrm{R} 2 \mathrm{~B}$ and $\mathrm{F}$ strain allantoic fluid samples were subjected to HI test for the confirmation of NDV by using constant antigen (4HA units) and serially diluted known NDV anti-serum. All the 13 samples and the reference R2B and F strain allantoic fluid sample were found positive for HI activity. Among these eight samples $(61.53 \%)$ had HI titer of $1: 16$ and below, three samples $(23.07 \%)$ had titer between $1: 16$ and $1: 64$, and two samples (15.38\%) had titer between 1:128 and 1:512. This approach was necessary to confirm the specific nature of HA activity. The finding of present study i.e. HA and HI activity of field samples further confirmed that all the 23 flocks were established cases of virulent NDV (VNDV) infection and the disease occurred on these farms in spite of regular prevention programme.

\section{Pathotyping by ICPI}

As per OIE, the ICPI test is scoring systems that evaluate illness or death in chickens. The values in the ICPI test range from 0 to 2.0. The most virulent 
viruses approach the ICPI value near 2.0, while lentogenic strains are usually close to 0.0 . For velogenic strains, the cut-off value of ICPI score is 0.7 . The ICPI value found during the present study from all thirteen samples was 2.0 and indicative of velogenic nature of the field NDV strains.

\section{Discussion}

The present findings of the epidemiological studies of the ND outbreaks in layer farms when viewed with the context of earlier workers, gave impression that mortality due to ND in spite of vaccination which included Genotype II virus strain could reach above $50 \%$ among layer flocks. The younger flocks appeared more susceptible due to low vaccinal immunity and because of less number of vaccinations. It was also seen that flocks with ND killed vaccination had relatively low mortality. The susceptible age of the disease was found 6-14 weeks among layer flocks, duration of mortality observed was 23 days among layer farms which all above are in agreement with earlier studies carried out by Saidu and Abdu [12] and Gowthaman et al. [13]. The disease resulted in significant reduction in body weight and feed consumption both in layer farms and in addition to this drop in egg production (20-30\%) in laying flocks is according to beach [14]. The outbreaks were appeared during extreme hot months of April to June in layer flocks. Similar findings were reported by Premavathi and Vardhani [15], Njagi et al. [16] and Leow et al. [17].

The findings of present field isolates obtained from layer flocks as Genotype XIII (XIIIb) by F gene sequence and whole genome sequence confirmed that mortality and production losses in the present outbreaks were due to highly virulent nature of Genotype XIII pathotype of NDV which supports findings of Tirumurugaan et al. [18] who reported that current vaccination programme against ND in layer and broilers which include genotype-II virus strain like Lasota, $\mathrm{B}_{1}$ or Komarov does not prevent the clinical disease against velogenic pathotype VII, the present Genotype XIII might have resulted in vaccine failure and resultant outbreaks with heavy mortality.

Similar clinical signs like reduced feed intake, weight loss, depression, somnolence, leg paralysis, watery greenish diarrhoea, and difficult respiration were also reported by Premavathi and Vardhani [15] and Akamura et al. [19] during field outbreaks of ND in vaccinated flocks.

Clinical signs such as listlessness, ruffled feathers, prostration, periocularedema, green diarrhea were similar to as reported by Merino et al. [20] during their experimental study on broilers infected with Quail 2006 (Genotype V) NDV strains following to vaccination with Genotype II NDV strains.

Lesions like multifocal to diffuse haemorrhages around proventricular glands, necrotic haemorrhagic ulcers throughout the intestine and caecal tonsils were similar to the findings observed by Saidu and abdu [12] in 6 weeks old pullets, Gowthaman et al. [14] who reported disseminated multiple foci of necrosis and pin-point haemorrhages in spleen parenchyma in grower and layer birds affected with virulent Newcastle disease (VND). Pazhanivel et al. [21] also reported same lesions like severe congestion of trachea and lungs in vaccinated broiler coloured chicken. The gross lesions observed during the present study were also in agreement with the findings of earlier workers Akamura et al. [19], Wang et al. [22] and $\mathrm{Hu}$ et al. [23] who reported lesions with more or less severity among vaccinated layer farms.

The histopathological lesions observed in different visceral and lymphoid organs during the present study indicated that the Genotype XIII NDV cause significant pathological lesions in proventriculus, intestine, trachea, lungs as well as lymphoid organs like caecal tonsils, spleen, and bursa of fabricius. Overall nature of histopathological lesions also suggested that present outbreaks caused by Genotype XIII NDV were similar to that of classical viscerotropic velogenic ND. Outbreaks leading to immunosuppression which were in agreement with the findings of Ezema et al. [24] who reported that VNDV cause marked atrophy of the lymphoid organs, leading to immunosuppression in vaccinated chickens and stated that LaSota vaccination may not protect against the VND in chickens and Wang et al. [22] who showed severe lymphoid necrosis in lymphoid organ during their study on SPF chickens experimentally infected with JS-5-05-Go (Genotype VIId), ZJ1 (Genotype VIId), XJ-2/97 (Genotype VIId), JS-3-05-Ch (Genotype VIId) strains.

The clinical signs, mortality pattern and postmortem lesions observed during the present outbreaks of ND in layer farms were suggestive of very virulent Newcastle disease. The present available vaccines prepared from Genotype-II NDV probably have failed in protecting flocks from Genotype-XIII NDV infection. Similar method of virus isolation from tissues by using SPF embryonated eggs through intra allantoic inoculation and death of the embryos within 24-96 h of post-inoculation was reported by Tirumurugaan et al. [25], Diel et al. [26], Fringe et al. [27] and Majed et al. [28] during their study.

In present study 13 clinically suspected layer farms are positive for NDV similar to Majed et al. [28], who isolated NDV using SPF chicken embryos through chorio-allantoic membrane route from 26 samples out of 34 clinically diagnosed ND field samples. In the present study the observation of death of all the embryos following inoculation with presence of petechial or ecchymotic haemorrhages throughout the body surface were in accordance with the results of Fringe et al. [27] and Haque et al. [29]. The present HA activity results of NDV field isolates were in accordance with the reports of Rakibul Hasan et al. [30] and Gowthaman et al. [31].

The present findings of NDV confirmation by HI were in accordance with earlier reports of 
RakibulHasan et al. [30] and Tirumurugaan et al. [18]. In present study $13 \mathrm{HA}$ positive NDV allantoic fluid was also found positive by HI. It is similar to Majed et al. [28] who reported that out of 26 HA positive NDV suspected allantoic fluid, 19 (73.08\%) were positive by HI. The finding of present study i.e. HA and $\mathrm{HI}$ activity of field samples further confirmed that all the 13 flocks were established cases of VNDV infection and the disease occurred on these farms in spite of regular prevention programme.

Present study all 13 layer farms found ICPI 2.0 which were characterstics of Velogenic NDV. The results of the present study were in accordance with the previous work of Ananth et al. [32], Tirumurugaan et al. [18], Munir et al. [33], Al-Habeeb et al. [34] and Naveen et al. [35]. Result was also in accordance to Kianizadeh et al. [36] who recovered 12 isolates of NDV from different outbreaks in Iran. They found ICPI varying from 1.7 to 1.96 and described them as characteristic velogenic NDV. Isolation of novel Genotype-XIII from the field outbreaks and ICPI score of 2.0 confirmed that present outbreaks were due to Genotype-XIII NDV which was velogenic in nature.

\section{Conclusion}

Commercial layer farms which showed ND outbreaks had undergone routine preventive ND vaccination programme. The management of these farms was well acquainted with appropriate vaccination procedure. Isolation of Genotype-XIII and its virulent nature from the field outbreaks also confirmed the limitations of the presently available live and inactivated vaccines to protect the flocks against GenotypeXIII NDV infection. The present outbreaks of NDV infection in layer farms were due to velogenic nature of virus Genotype-XIII and presently available vaccines have limited protection against this genotype.

\section{Authors' Contribution}

This study is the major component of the work towards the M.V.Sc thesis of the first author JHK under the guidance of the second author BPJ and KSP, SP, PDG helped in the experimental investigation and organized the manuscript. DJG and RAM thoroughly revised the same and provided guidance for research work. All authors read and approved the final version of the manuscript.

\section{Acknowledgements}

The authors express profound gratitude to Anand Agricultural University, Anand, Gujarat and Dean, College of Veterinary Science and Animal Husbandry, A.A.U. for providing the infrastructure facilities as well as financial help to carry out the research work.

\section{Competing Interests}

The authors declare that they have no competing interests.

\section{References}

1. The economic times (2013) http://articles.economictimes. indiatimes.com/2013-05-21/news/39418822_1_poultry-sector-poultry-farmers-table-egg-production access on $3^{\text {rd }}$ march 2014.

2. Aldous, E.W. and Alexander, D.J. (2001) Detection and differentiation of new castle disease virus (Avian paramyxotype I). Avian. Pathol., 30: 117-128.

3. Nanthakumar, T., Kataria, R.S., Tiwari, A. K., Butchiah, G. and Kataria, J. M. (2000) Pathotyping of New castle disease virus by RT-PCR and restriction enzyme analysis. Vet. Res. Communication, 24: 275-286.

4. Edwards, J.J. (1928) A new fowl disease. Ann. Rep. Imp. Inst. Vet. Res. Mukhteswar 1978.

5. Kylasam, Aier. (1930) A study on Madras fowl pest. Ind. Vet. J., 8: 346-352.

6. International Committee on Taxonomy of Viruses, 9th Report. (2009), Virus Taxonomy: 2102 Release.

7. Briand, F.X., Henry, A., Masinand, P. and Jestin, V. (2012) Complete genome sequence of a novel avian paramyxovirus. J. Virol., 86(14):7710.

8. Susta, L., Jones, M. E. B., Cattoli., Cardenas-Garcia., Miller, P. J., Brown, C. C. and Afonso, C. L. (2014) Pathologic Characterization of Genotypes XIV and XVII Newcastle Disease Viruses and Efficacy of Classical Vaccination on Specific Pathogen-Free Birds. Vet. Pathol., 1: 2.

9. Luna, L. G. (1968) Manual of histologic staining methods of the armed forced institute of Pathology, 3rd edition New York, McGraw Hill Book Company.

10. OIE Terrestrial Manual. (2012) Newcastle disease. In: Manual of standards for diagnostic tests and vaccines. www.oie.int/fileadmin/Home/eng/Health Standards/ tahm/2.3.14 NEWCASTLE DIS.pdf.

11. Alexander, D.J. and Senne, D.A. (2008) Newcastle Disease and other Avian Paramyxoviruses. In: A Laboratory Manual for the Isolation, Identification and Characterization of Avian Pathogens, Dufour-Zavala L. (Editor in Chief) Swayne, D. E., Glisson, J.R., Jackwood, M.W., Pearson, J.E., Reed, W.M, Woolcock, P.R., 4th ed., American Association of Avian Pathologists, Athens, pp. 135-141.

12. Saidu, L. and Abdu, P.A. (2008) Outbreak of Viscerotropic Velogenic form of Newcastle dis-ease in vaccinated six weeks old pullets. Sokoto Journal of Veterinary Sciences, 7(1): 2

13. Gowthman, V., Singh, S. D., Dhama, K., Barathidasan, R., Srinivasan, P., Saravanan, S., Sukumar, K., Pandey, A.B. and Ramakrishnan, M.A. (2013) Pathology of Co-infections of low pathogenic avian influenza and virulent Newcastle disease in growers and layers-A field Observations. Compendium Abstracts Veterinary Pathology Congress. 3: 159 .

14. Beach, J. R. (1943) Avian Pneumoencephalitis. Proc. $46^{\text {th }}$ An. Meet., U. S. Livestock Sanitary Assoc, pp. 203-223.

15. Premavathi, K. and Vardhani, V.V. (2007) Incidence of Ranikhet disease in Broilers of organized farms in India. Ecology, Environment and Conservation Paper, 13(1): 187-190

16. Njagi, L. W., Nyaga, P. N. and Uema, M. (2010) A retrospective study of factors associated with Newcastle disease outbreaks in village indigenous chickens. Bull. Anim. Health. Prod. Afr., 58: 22-33.

17. Leow, B. L., Shajarutulwardah, M. Y. and Ramlan, M. (2011) Newcastle disease in Malaysia: diagnostic cases in veterinary research institute (VRI) IPOH from 2004-2009. Malaysian Journal of Veterinary Research. 2(1): 45-51

18. Tirumurugaan, K. G., Vinupriya, M. K., Vijayarani, K. and Kumanan, K. (2011b) Analysis of the fusion protein cleavage site of Newcastle disease virus isolates from India reveals preliminary evidence for the existence of II, VI and VII genotypes. Indian J. Virol., 22(2): 131-137.

19. Akamura, K. N., Htsu, N. O., Akamura, T. N., 
Amamoto, Y. Y., Amada, M. Y., Mase, M. and Imai, K. (2008) Pathologic and Immunohistochemical Studies of Newcastle Disease (ND) in Broiler Chickens Vaccinated with ND: Severe Nonpurulent Encephalitis and Necrotizing Pancreatitis. Vet. Pathology online.,45: 928-933.

20. Merino, R., Hilda, V., Jose, A., Quintana and Norma, C. (2011) Comparison of the Virulence of Pathogenic Newcastle Disease Viruses Belonging to the Same or Different Genotypes. Int. J. Poultry Sc., 10(9): 713-720.

21. Pazhanivel, N., Vijayalingam, T. A., Thangathurai, R., Kumar, V., Nithya, P. and Thanaseelan, V. (2013). Concurrent Newcastle disease and taeniasis in a coloured broiler chicken. Compendium Abstracts Veterinary Pathology Congress., 3: 153.

22. Wang, Yuyang., Zhiqiang, Duan., Shunlin, H., Yan, Kai., Xiaobo, Wang., Qingqing, Song., Lei, Zhong., Qing, Sun., Xiaoquan, Wang., Yantao, Wu. andXiufan, Liu. (2012) Lack of detection of host associated differences in Newcastle disease viruses of genotype VIId isolated from chickens and geese. Virol. J., 9: 197.

23. Hu, Zenglei., Hu, Jiao., Hu, Shunlin., Liu, Xiaowen., Wang, Xiaoquan., Zhu, Jie. and Liu, Xiufan. (2012) Strong innate immune response and cell death in chicken splenocytes infected with genotype VIId Newcastle disease virus. Virol. J., 9: 208 .

24. Ezema, W.S., Okoye, J.O.A. andNwanta, J.A. (2009) LaSota vaccination may not protect against the lesions of velogenic Newcastle disease in chickens. Trop. Anim. Health Prod., 41(4): 477-84.

25. Tirumurugaan, K. G., Kapgate, S., Vinupriya, M. K., Vijayarani, K., Kumanan, K and Elankumaran, S. (2011a) Genotypic and pathotypic characterization of ND viruses from India. PLoS ONE 6(12): e28414.

26. Diel, D. G., Susta, L., Garcia, S. C., Killian, M. L., Brown, C. C., Miller, P. J. and Afonso, C. L. (2011) Complete Genome and Clinico-pathological characterization of a virulent Newcastle disease virus isolate from South America. J. Clin. Microbiol., 50(2): 378-387.

27. Fringe, R., Bosman, A. M., Ebersohn, K., Bisschop, S., Abolnik, C. and Venter, E. (2012) Molecular characterisation of Newcastle disease virus isolates from different geographical regions in Mozambique in 2005. Onderstepoort J. Vet. Res., 79(1), Art. \#409, 7 pages. http:// dx.doi.org/10.4102/ojvr.v79i1.409.

28. Majed, H. M., Zahid, A. A. H., Kadhim, L. I., and Hasoon, M. F. (2013) Conventional and molecular detection of Newcastle disease and infectious Bursal disease in chickens. JWPR., 3(1): 05-12.

29. Haque, M. H., Hossain, M. T., Islam, M. T., Zinnah, M. A., Khan, M. S. R. and Islam, M. A. (2010) Isolation and detection of NDV from field outbreaks in broiler and layer chickens by RT-PCR. Bangl. J. Vet. Med., 8(2): 87-92.

30. Rakibul, H. A. K. M., Ali, M. H., Siddique, M. P., Rahman, M. M. and Islam, M. A. (2010) Clinical and laboratory diagnoses of Newcastle and Infectious bursal diseases of chickens. Bangl. J. Vet. Med., 8(2): 131-140.

31. Gowthaman, V., Singh, S. D., Dhama, K., Barathidasan, R., Anjaneya. And Ramakrishnan, M.A. (2011). Pathology and molecular diagnosis of Newcastle disease virus infection in broiler breeders, Indian J. Vet. Pathol., 35(2):168-170.

32. Ananth, R., Kirubaharan, J. J., Priyadarshini, M. L. M. and Albert, A. (2008) Isolation of Newcastle Disease Viruses of High Virulence in Unvaccinated Healthy Village Chickens in South India. Int. J. Poultry Sci., 7(4): 368-373.

33. Muhammad, M., Muhammad, A., Muhammad, T., Siamak, Z. and Mikael B. (2012) Genomic and biological characterization of a velogenic Newcastle disease virus isolated from a healthy backyard poultry flock in 2010. Virol. J., 9: 46.

34. Al-Habeeb, M. A., Mohamed, M. H. A. and Sharawi, S. (2013) Detection and characterization of Newcastle disease virus in clinical samples using real time RT-PCR and melting curve analysis based on matrix and fusion genes amplification. Vet. World, 6(5): 239-243.

35. Naveen, K. A., Singh, S. D., Kataria, M., Barathidasan, R. and Dhama, K. (2014) Molecular characterization and phylogenetic analysis of selected pigeon paramyxovirus type-1 (PPMV-1) Indian isolates. J. Biol. Sci.,14(2): 134-141.

36. Kianizadeh, M., Ideris, A., Shahrabadi, M. S., Kargar, R., Pourbakhsh, S. A., Omar, A. R. and Yusoff, K. (1999) Biological and Molecular Characterization of Newcastle Disease Virus Isolated from Iran. Arch. Razi Ins. 50. 